\title{
ESSENTIAL OIL COMPOSITION OF SWEET BASIL (OCIMUM BASILICUM L.) IN SYMBIOTIC RELATIONSHIP WITH PIRIFORMOSPORA INDICA AND PACLOBUTRAZOL APPLICATION UNDER SALT STRESS
}

\author{
Sara Keramati, ${ }^{1 *}$ Hemmatollah Pirdashti, ${ }^{1}$ \\ Valliollah BabaeizaD ${ }^{2}$ and Ali Dehestani ${ }^{1}$ \\ ${ }^{1}$ Department of Agronomy, Genetic and Agricultural Biotechnology Institute of Tabarestan, \\ Sari Agricultural Sciences and Natural Resources University, Sari, Iran \\ ${ }^{2}$ Department of Phytopathology, Sari Agricultural Sciences and Natural Resources University, Sari, Iran \\ Km 9 Farah Abad Road, P.O. Box: 578, Sari, Iran
}

(Received: March 21, 2016; accepted: June 14, 2016)

\begin{abstract}
Essential oil content and oil composition of paclobutrazol treated sweet basil (Ocimum basilicum L.) plant inoculated with Piriformospora indica under salt stress were investigated by GC-MS. The results show a slight increase in essential oil content when basil plants subjected to moderate salinity stress $\left(3 \mathrm{dS} \mathrm{m}^{-1}\right.$ of $\mathrm{NaCl}$ ). It decreased significantly with increasing salinity level to $9 \mathrm{dS} \mathrm{m}^{-1}$. The findings revealed that leaf area, above ground and leaf dry weights, essential oil content and yield were significantly affected by $P$. indica inoculation, however paclobutrazol application significantly influenced essential oil yield but not content. Fungal symbiosis as well as paclobutrazol application ameliorated the negative effects of salinity on dry matter and essential oil yield. The main constituents found in the volatile oil of $O$. basilicum in control treatment were Geranial (26.03\%), Neral (24.88\%) and Estragole (24.78\%). The compounds concentrations showed some differences in P. indica and paclobutrazol treatments. The results demonstrate that micorrhiza-like fungi concomitantly increase essential oil production and biomass in sweet basil, a medicinal herb rich in commercially valuable essential oils.
\end{abstract}

Keywords: Essential oil - GC-MS - Ocimum basilicum - paclobutrazol - Piriformospora indica salinity

\section{INTRODUCTION}

Essential oils are the most important raw materials of the fragrance and cosmetic [26], food and pharmaceutical industries due to their therapeutic, antimicrobial and antioxidant activities [14, 27]. It has also been proven that they have biological activities that make them suitable to be used as herbicides, pesticides and anticancer compounds [20]. In this regard, common basil (Ocimum basilicum L.) is one of the most important essential oil crops which are cultivated commercially in many countries. The essential oil of $O$. basilicum is used as perfumery [7], and medicinal plant in folk medicine [27]. Also, antiviral and antimicrobial activities of basil essential oil have been reported [14].

In recent years, researchers are looking for new strategies to deal with salinity in order to minimize its negative effects. One of these methods is application of benefi-

\footnotetext{
*Corresponding author; e-mail address: sara.keramati@gmail.com
} 
cial microorganisms (such as symbiotic fungi, bacteria, etc.) to improve growth and increase plant performance. Beneficial fungi improve plant growth and performance as well as enhance host plant tolerance to environmental stresses. They are also involved in phytoremediation, food safety and sustainable production of agricultural products [3].

Piriformospora indica, is one of these beneficial fungi, a plant root endophytic fungi which was isolated from the desert soil of northwest India in the state of Rajasthan [23]. It co-exists with roots of many plant species and promotes their growth and performance [18]. It increases plant resistance to biotic and abiotic environmental stresses such as diseases [11], heavy metals [29], drought [21] and salinity $[3,5]$. The symbiotic interaction of endophytic fungi resulted into higher biomass production of the aerial parts of the plant along with floral parts which can be utilized in pharmaceutical industries for medicinally important chemical production. Its metabolic interaction may also favor the synthesis of biologically active secondary metabolites [13].

On the other hand, besides the application of biotic factors in order to alleviate the negative effects of environmental stresses, in recent years, the use of materials with plant growth regulator (PGR) properties has increased in agriculture. Paclobutrazol (PBZ), a triazole derivative which has been used to mitigate environmental stress in some crops. PBZ-mediated stress protection is often explained in terms of hormonal changes [16].

This study was carried out to elucidate the $P$. indica fungi influence on performance of $O$. basilicum plants, especially in saline condition. We comprehensively investigated the alleviative effects of $P$. indica or paclobutrazol on basil plants under salt stress.

\section{MATERIALS AND METHODS}

\section{P. indica inoculum preparation}

The endomycorrhizal fungus $P$. indica culture was kindly gifted by Prof. Kogel, Head of IPAZ institute, University of Giessen, Germany. P. indica was cultured in liquid Kafer's medium [15] at $24^{\circ} \mathrm{C}$ in 2 weeks.

\section{Root colonization assay}

Roots of inoculated basil were washed thoroughly under running tap water and cut into $1 \mathrm{~cm}$ pieces. Segments were stained following the method described by Vierheilig et al. [24]. The root-pieces were examined under light microscope at the magnification of $\times 10-40$ (Fig. 1). 

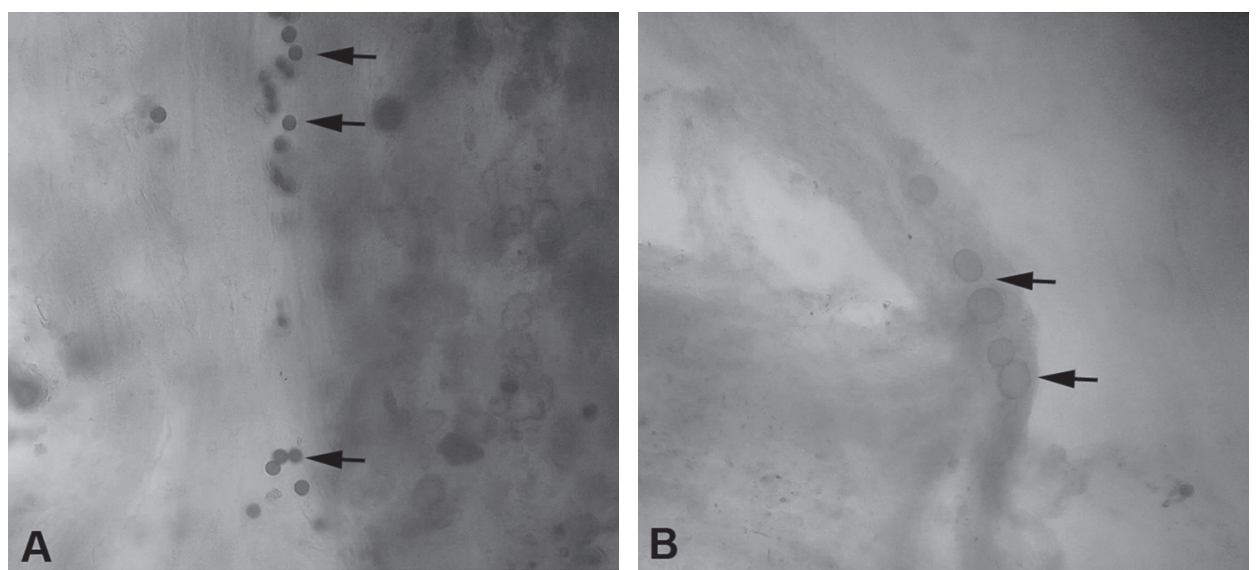

Fig. 1. Development of P. indica (arrows) in root cells of 3 weeks old basil plants. A: $\times 10$; B: $\times 40$

\section{Plant materials}

A field experiment with factorial arrangement based on randomized complete block design with three replications was conducted. Treatments were fungi inoculation (inoculated and uninoculated control); application of four different salinity levels ( 0 , 3, 6, $9 \mathrm{dS} \mathrm{m}^{-1}$ of $\left.\mathrm{NaCl}\right)$, and paclobutrazol application $\left(0,20,40 \mathrm{mg} \mathrm{L}^{-1}\right)$.

Local sweet basil seeds were surface sterilized by dipping in 10 percent sodium hypochlorite solution for 5 minutes, then rinsed with sterilized distilled water. The seeds were divided into two parts: one without inoculation and another unit inoculated by dipping in suspension for 3 hours. Then the seeds were sown in farm with sandy-loam soil texture, $\mathrm{pH}=7.26$ and E.C. $=0.63 \mathrm{dS} \mathrm{m}^{-1}$. Paclobutrazol foliar spraying was performed on the six-leaf-stage of the plants, and one week later, salinity treatment started. Sampling for growth parameters started at early flowering stage.

\section{Essential oil extraction}

Aerial parts of cultivated $O$. basilicum at flowering stage were collected in summer (June 2015) during daytime (10-12 a.m.). They were dried in shades, and leaves were then separated and collected. Essential oil was extracted using hydro-distillation in a Clevenger apparatus. Each sample (50 g) was placed in a 2 liter round bottomed flask containing $1.5 \mathrm{~L}$ of water and refluxed for $3 \mathrm{~h}$. After completion and recording of the volume $(\mathrm{mL})$, the oil was collected in amber flasks and stored in freezer at $-20{ }^{\circ} \mathrm{C}$ until GC/MS analysis. 


\section{Analysis of the essential oil composition by GC/MS}

Essential oil composition was analyzed by GC/MS using Agilent Technologies 7890 equipped with a HP-5MS fused silica column $(30 \mathrm{~m} \times 0.25 \mathrm{~mm}$; film thickness 0.25 $\mu \mathrm{m})$, in the following conditions: helium as carrier gas at $1 \mathrm{~mL} \mathrm{~min}^{-1}$; injector split at $250{ }^{\circ} \mathrm{C}$ (split ratio 1:100); detector at $280{ }^{\circ} \mathrm{C}$, column temperature program was 60 ${ }^{\circ} \mathrm{C}$ for $3 \mathrm{~min}$, followed by $4{ }^{\circ} \mathrm{C} / \mathrm{min}$ to $240{ }^{\circ} \mathrm{C}$, then $10{ }^{\circ} \mathrm{C} / \mathrm{min}$ to $270{ }^{\circ} \mathrm{C}$, ending with a $3 \mathrm{~min}$ isothermal at $270^{\circ} \mathrm{C}$. The mass spectra were taken at $70 \mathrm{eV}$. The identification of the constituents was done by computerized matching of the acquired mass spectra (MS5975) with those stored in NIST21 and wailly07 mass spectral libraries of the GC/MS data system and other published mass spectra [1].

\section{Statistical analysis}

Data were analyzed using SAS (9.1) statistical program and means were compared using an LSD test $(\mathrm{p}<0.05)$.

\section{RESULTS}

\section{Essential oil content}

The findings of this study show that $O$. basilicum essential oil content and essential oil yield decreased significantly with salinity increase (Table 1). However, there was a slight increase (3\% compared to the control) in essential oil content when basil plants were subjected to moderate salinity stress $\left(3 \mathrm{dS} \mathrm{m} \mathrm{m}^{-1} \mathrm{NaCl}\right)$. Compared to the control, $8 \%$ reduction was recorded in essential oil content when salinity was increased to $6 \mathrm{dS} \mathrm{m}^{-1}$. This decline was more noticeable when salinity reached to $9 \mathrm{dS} \mathrm{m}^{-1}$ and almost decreased to the half (52\% reduction) (Table 1$)$.

$P$. indica symbiosis with basil improved essential oil content by $2 \%$, compared to the uninoculated control. Hence, essential oil yield significantly increased in fungiinoculated treatments (51\% higher than after control treatment). On the other hand, PBZ foliar spray increased essential oil content, however, the increase was not significant. Inoculation with $P$. indica and application of PBZ ameliorate the negative effects of salinity on basil dry matter and essential oil yield (Table 2).

\section{Plant leaf and aerial dry weight}

As expected, the results showed that increased salinity significantly reduced plant leaf and aerial dry weight (Table 1). Leaf and aerial dry weight reached to the lowest level in $9 \mathrm{dS} \mathrm{m}^{-1}$ of salinity ( $45 \%$ and $60 \%$, respectively, compared to the control). However, 
Table 1

Effect of Piriformospora indica symbiosis, paclobutrazol foliar spray and soil salinity on Ocimum basilicum plants

\begin{tabular}{|c|c|c|c|c|c|c|}
\hline & & $\begin{array}{l}\text { Leaf area } \\
\left(\mathrm{cm}^{2} \text { plant }{ }^{-1}\right)\end{array}$ & $\begin{array}{l}\text { Aerial dry } \\
\text { weight } \\
\left.\text { (g plant }^{-1}\right)\end{array}$ & $\begin{array}{l}\text { Leaf dry weight } \\
\qquad\left(\text { g plant }^{-1}\right)\end{array}$ & $\begin{array}{l}\text { Essential oil } \\
\text { content (\%) }\end{array}$ & $\begin{array}{l}\text { Essential oil } \\
\text { yield } \\
\left(\mathrm{L} \mathrm{ha}^{-1}\right) \\
\end{array}$ \\
\hline \multirow{2}{*}{ Fungi } & $-\mathrm{Pi}$ & $513.94 b$ & $8.388 b$ & $3.03 \mathrm{~b}$ & $0.716 b$ & $9.4122 b$ \\
\hline & $+\mathrm{Pi}$ & $614.48 \mathrm{a}$ & $9.703 \mathrm{a}$ & $4.773 \mathrm{a}$ & $0.733 \mathrm{a}$ & $14.253 \mathrm{a}$ \\
\hline LSD at 0.05 & & 16.805 & 0.388 & 0.1742 & 0.0054 & 0.5905 \\
\hline \multirow{3}{*}{$\begin{array}{l}\text { Paclobutrazol } \\
\left(\mathrm{mg} \mathrm{l}^{-1}\right)\end{array}$} & 0 & $567.43 a$ & $9.119 \mathrm{ab}$ & $4.228 \mathrm{a}$ & $0.721 b$ & $12.945 \mathrm{a}$ \\
\hline & 20 & $565.69 \mathrm{a}$ & $8.691 \mathrm{~b}$ & $3.792 b$ & $0.724 a b$ & $11.471 \mathrm{~b}$ \\
\hline & 40 & $559.51 \mathrm{a}$ & $9.329 \mathrm{a}$ & $3.684 \mathrm{~b}$ & $0.728 \mathrm{a}$ & $11.082 \mathrm{~b}$ \\
\hline LSD at 0.05 & & 20.581 & 0.4752 & 0.2134 & 0.0066 & 0.7232 \\
\hline \multirow{4}{*}{$\begin{array}{l}\text { Salinity } \\
\left(\mathrm{dS} \mathrm{m}^{-1}\right. \\
\mathrm{NaCl})\end{array}$} & 0 & $774.01 \mathrm{a}$ & $12.531 \mathrm{a}$ & $5.21 \mathrm{a}$ & $0.846 \mathrm{~b}$ & $17.629 \mathrm{a}$ \\
\hline & 3 & $636.96 b$ & $10.488 b$ & $4.104 b$ & $0.869 \mathrm{a}$ & $14.313 b$ \\
\hline & 6 & $496.56 \mathrm{c}$ & $8.168 \mathrm{c}$ & $3.434 \mathrm{c}$ & $0.778 \mathrm{c}$ & $10.699 \mathrm{c}$ \\
\hline & 9 & $349.32 \mathrm{~d}$ & $4.998 \mathrm{~d}$ & $2.857 \mathrm{~d}$ & $0.405 \mathrm{~d}$ & $4.689 \mathrm{~d}$ \\
\hline LSD at 0.05 & & 23.765 & 0.5487 & 0.2464 & 0.0076 & 0.8351 \\
\hline
\end{tabular}

Means in a column followed by the same letter are not significantly different at $P \leq 0.05$.

symbiosis relationship with $P$. indica helped basil to ameliorate the negative effect of salinity on dry matter. Compared to the control the most positive effect of symbiosis was observed in medium and high levels of salinity with $77 \%$ and $15 \%\left(6 \mathrm{dS} \mathrm{m}^{-1}\right)$ $187 \%$ and $75 \%\left(9 \mathrm{dS} \mathrm{m}^{-1}\right)$ leaf and plant aerial dry weight, respectively, improvement compared to the control (Table 2). PBZ application remarkably decreased basil dry matters in control treatments. However, under salinity condition, PBZ significantly enhanced basil leaf and plant aerial dry weight, especially in medium and high levels of salinity. The highest increase was observed in $40 \mathrm{mg} \mathrm{L}^{-1}$ of PBZ (Table 2).

\section{Leaf area}

Salt stress significantly reduced basil leaf area. The findings show that inoculation with $P$. indica significantly ameliorate the negative effect of salt stress on leaf area, the improvement was more significant in high $\left(9 \mathrm{dS} \mathrm{m}^{-1}\right)$ level of salinity $(59 \%$ higher compared to uninoculated control, whereas the improvement in the $0 \mathrm{dS} \mathrm{m}^{-1}$ of salinity was only 10\%). In normal condition, PBZ application reduced basil leaf area but the reduction was not significant, while under salinity condition, PBZ foliar spray significantly alleviated the negative effects of salt stress on basil leaf area (in 9 dS m$~^{-1}$ level of salinity, $14 \%$ in $20 \mathrm{mg} \mathrm{L}^{-1}$ and $39 \%$ in $40 \mathrm{mg} \mathrm{L}^{-1} \mathrm{PBZ}$ compared to the control). 


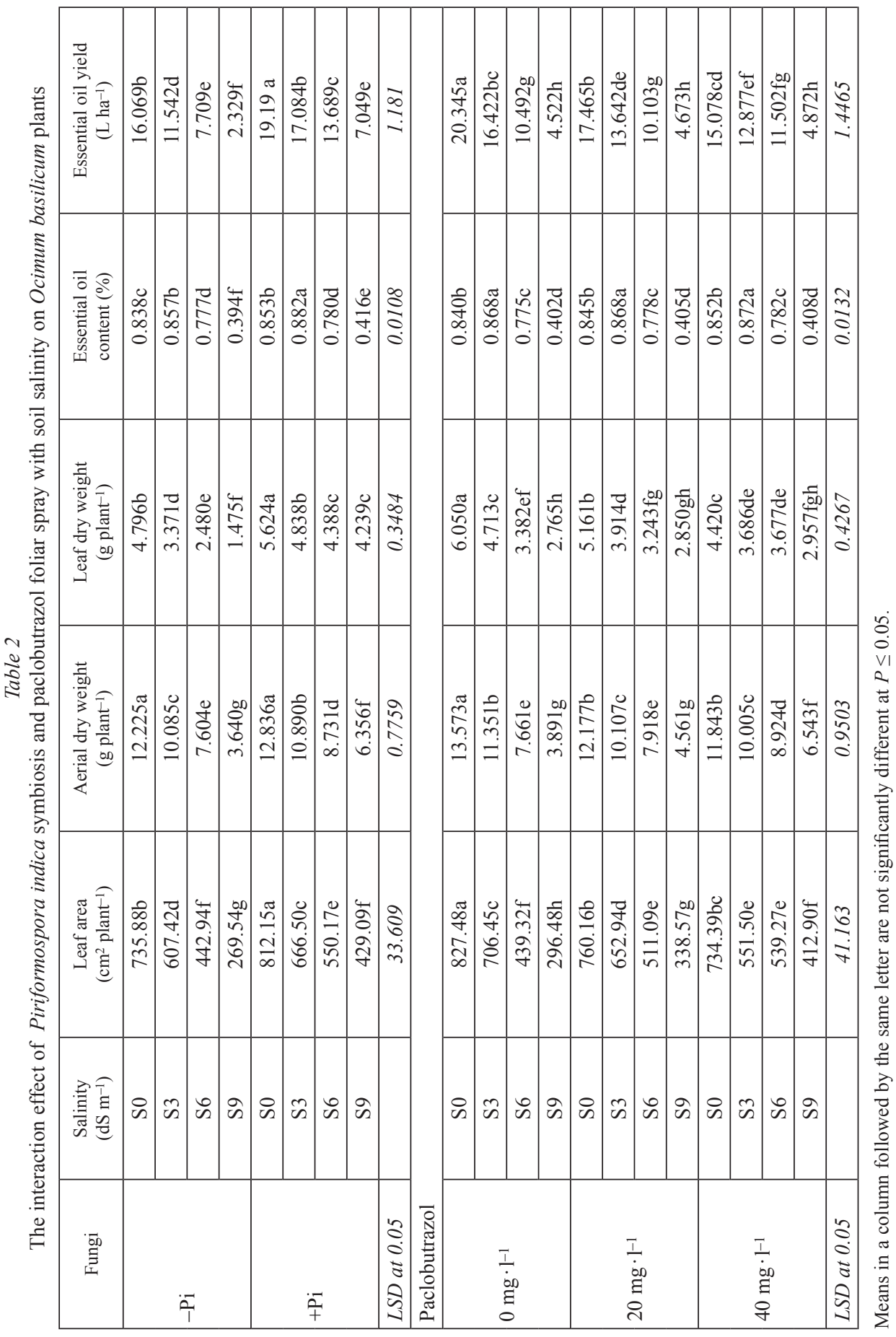




\section{Essential oil components}

The essential oils of basil after control treatment were geranial $(26.03 \%)$ as the major component, neral $(24.88 \%)$ as the second main component, and estragole $(24.78 \%)$ as the third component (Table 3 ).

As expected, oil composition was slightly different after salinity, inoculation and PBZ spraying treatments under normal and stressful condition. It can be seen that the three samples represented in Table 3 (control, $P$. indica and paclobutrazol under normal condition) contained a significant amount of geranial $(26.03 \%, 27.32 \%$ and $26.49 \%$, respectively), estragole $(24.78 \%, 24.86 \%$ and $24.12 \%$, respectively) and neral $(24.88 \%, 24.98 \%$ and $24.16 \%$ respectively). The results in Table 3 show that inoculation resulted in the highest content of (6-methyl-5-hepten-2-one; D-limonene; eucalyptol; estragole; neral; geranial; 2,6-Octadien-1-ol, 3,7-dimethyl-, and geraniol) and PBZ treatment gave the highest content of ( $\gamma$-terpinene; cyclohexanone 5-methyl2-(1-methylethenyl); 1-tert-butyl-3,3-dimethylcyclopentene; ethenyl-cyclohexane; eugenol and caryophyllene; caryophyllene oxide) in basil plant essential oil composition under in normal condition. However, essential oil composition showed some differences under increased salinity condition, especially when the plant was treated with $P$. indica and PBZ (data not shown).

Table 3

Effect of P. indica inoculation and paclobutrazol application on percentage composition of Ocimum basilicum essential oils in normal condition

\begin{tabular}{|c|l|c|c|c|c|}
\hline \multirow{2}{*}{ No Compound } & \multirow{2}{*}{} & \multicolumn{4}{c|}{ Concentration (\%) } \\
\cline { 3 - 6 } & & Rt & Control & $\begin{array}{c}\text { Inoculation with } \\
\text { P. indica }\end{array}$ & $\begin{array}{c}\text { Paclobutrazol } \\
\left(40 \mathrm{mg} \cdot \mathrm{l}^{-1}\right)\end{array}$ \\
\hline 1 & $\alpha$-Pinene & 4.91 & 0.07 & 0.11 & 0.10 \\
\hline 2 & B-Pinene & 6.05 & 0.04 & 0.07 & 0.06 \\
\hline 3 & 1-Octen-3-ol & 6.15 & - & 0.06 & 0.06 \\
\hline 4 & 6-Methyl-5-hepten-2-one & 6.37 & 0.72 & 0.94 & 0.81 \\
\hline 5 & B-Myrcene & 6.48 & - & 0.10 & 0.09 \\
\hline 6 & Octanal & 6.85 & - & 0.07 & 0.07 \\
\hline 7 & D-Limonene & 7.61 & 0.48 & 0.60 & 0.39 \\
\hline 8 & Eucalyptol & 7.68 & 0.18 & 0.35 & 0.22 \\
\hline 9 & Benzeneacetaldehyde & 8.11 & - & 0.11 & 0.14 \\
\hline 10 & $\beta$-Ocimene & 8.26 & - & 0.09 & 0.08 \\
\hline 11 & $\gamma$-Terpinene & 8.58 & - & 0.11 & 0.23 \\
\hline 12 & Camphor & 9.54 & 0.13 & 0.14 & 0.14 \\
\hline 13 & Benzenemethanol, 4-(1-methylethyl)- & 9.89 & - & 0.20 & 0.19 \\
\hline 14 & Linalool & 9.99 & 0.22 & 0.16 & 0.18 \\
\hline 15 & Photocitral B & 10.05 & 0.11 & 0.14 & 0.15 \\
\hline
\end{tabular}


Table 3. (continued)

\begin{tabular}{|c|c|c|c|c|c|}
\hline \multirow[b]{2}{*}{ No } & \multirow[b]{2}{*}{ Compound } & \multicolumn{4}{|c|}{ Concentration (\%) } \\
\hline & & Rt & Control & $\begin{array}{l}\text { Inoculation with } \\
P . \text { indica }\end{array}$ & $\begin{array}{l}\text { Paclobutrazol } \\
\left(40 \mathrm{mg} \cdot \mathrm{l}^{-1}\right)\end{array}$ \\
\hline 16 & \pm -4-Acetyl-1-methylcyclohexene & 11.01 & 0.14 & 0.06 & 0.10 \\
\hline 17 & Methyl ethyl cyclopentene & 11.26 & 0.28 & 0.37 & 0.39 \\
\hline 18 & 1,5-Heptadiene, 2,6-dimethyl- & 11.51 & 0.17 & 0.29 & 0.28 \\
\hline 19 & 3,3-Dimethyl-hepta-4,5-dien-2-one & 11.64 & 0.51 & 0.66 & 0.69 \\
\hline 20 & $\begin{array}{l}\text { Cyclohexanone, 5-methyl-2-(1-mety- } \\
\text { lethy)- }\end{array}$ & 11.77 & 0.11 & 0.68 & 1.02 \\
\hline 21 & Photonerol B & 12.18 & 0.11 & - & - \\
\hline 22 & Menthofuran & 12.09 & - & 0.11 & 0.16 \\
\hline 23 & $\begin{array}{l}\text { 1-Tert-butyl-3,3- } \\
\text { dimethylcyclopentene }\end{array}$ & 12.20 & 0.77 & 1.28 & 1.31 \\
\hline 24 & $\begin{array}{l}\text { Cyclohexanol, 5-methyl-2-(1-methy- } \\
\text { lethenyl)- }\end{array}$ & 12.44 & 0.14 & 0.69 & 1.08 \\
\hline 25 & $\begin{array}{l}\text { Cyclohexanecarboxylic acid, 2-oxo-, } \\
\text { ethyl ester }\end{array}$ & 12.56 & 0.37 & 0.51 & 0.50 \\
\hline 26 & Ethenyl-cyclohexane & 12.84 & 1.23 & 1.69 & 1.73 \\
\hline 27 & $\alpha$-Terpineol & 13.11 & - & 0.10 & 0.11 \\
\hline 28 & Methyl chavicol (estragole) & 13.46 & 24.78 & 24.86 & 24.12 \\
\hline 29 & 2,6-Octadien-1-ol, 3,7-dimethyl- & 14.51 & 1.21 & 1.49 & 1.22 \\
\hline 30 & Neral (citral B) & 15.03 & 24.88 & 24.98 & 24.16 \\
\hline 31 & Geraniol & 15.42 & 0.29 & 0.44 & 0.28 \\
\hline 32 & Geranial (citral A) & 16.08 & 26.03 & 27.42 & 26.49 \\
\hline 33 & Camphene & 16.22 & - & 0.07 & - \\
\hline 34 & Carane & 16.62 & - & - & 0.11 \\
\hline 35 & Santolina triene & 16.70 & 0.12 & 0.08 & 0.10 \\
\hline 36 & Phenol, 2-methyl-5-(1-methylethyl)- & 16.85 & 0.09 & 0.14 & 0.20 \\
\hline 37 & $\begin{array}{l}\text { 2,6-Octadienoic acid, 3,7-dimethyl, } \\
\text { methyl ester }\end{array}$ & 17.56 & 0.15 & 0.12 & 0.14 \\
\hline 38 & $\alpha$-Cubebene & 18.31 & 0.06 & 0.07 & 0.08 \\
\hline 39 & Eugenol & 18.59 & 0.12 & 0.14 & 0.16 \\
\hline 40 & $\begin{array}{l}\text { Butanoic acid, 3,7-dimethyl-2,6-octa- } \\
\text { dienyl ester }\end{array}$ & 18.86 & 0.15 & 0.16 & 0.15 \\
\hline 41 & Copaene & 19.13 & 0.53 & 0.20 & 0.26 \\
\hline 42 & B-Bourbonene & 19.41 & 0.11 & 0.10 & 0.11 \\
\hline 43 & Hexanoic acid, 4-hexen-1-yl ester & 19.56 & 0.63 & 0.52 & 0.56 \\
\hline 44 & $\begin{array}{l}\text { Benzene, 1,2-dimethoxy-4-(2-prope- } \\
\text { nyl)- }\end{array}$ & 20.14 & 1.15 & 0.96 & 1.03 \\
\hline 45 & Caryophyllene & 20.50 & 1.95 & 2.17 & 2.19 \\
\hline
\end{tabular}


Table 3. (continued)

\begin{tabular}{|c|c|c|c|c|c|}
\hline \multirow[b]{2}{*}{ No } & \multirow[b]{2}{*}{ Compound } & \multicolumn{4}{|c|}{ Concentration (\%) } \\
\hline & & Rt & Control & $\begin{array}{c}\text { Inoculation with } \\
P . \text { indica }\end{array}$ & $\begin{array}{c}\text { Paclobutrazol } \\
\left(40 \mathrm{mg} \cdot \mathrm{l}^{-1}\right)\end{array}$ \\
\hline 46 & $\begin{array}{l}\text { Bicyclo[3.1.1]hept-2-ene, 2,6-dimeth- } \\
\text { yl-6-(4-methyl-3-pentenyl)- }\end{array}$ & 21.03 & 0.81 & 0.57 & 0.55 \\
\hline 47 & $\alpha$. -Caryophyllene & 21.54 & 0.85 & 0.92 & 1.03 \\
\hline 48 & $\begin{array}{l}\text { 1,6,10-Dodecatriene,7,11-dimethyl-3- } \\
\text { methylene- }\end{array}$ & 21.72 & 0.26 & 0.26 & 0.26 \\
\hline 49 & Germacrene D & 22.39 & 1.27 & 1.18 & 1.22 \\
\hline 50 & Naphthalene & 22.51 & 0.27 & 0.14 & 0.18 \\
\hline 51 & $\begin{array}{l}\text { Cyclohexene, 1-methyl-4-(5-methyl- } \\
\text { 1-methylene-4-hexenyl)- }\end{array}$ & 23.24 & 0.11 & 0.09 & 0.09 \\
\hline 52 & $\alpha$-Bergamotene & 23.66 & - & 0.17 & 0.17 \\
\hline 53 & cis- $\alpha$-Bisabolene & 24.27 & 1.68 & 1.33 & 1.33 \\
\hline 54 & Caryophyllene oxide & 25.35 & 0.77 & 0.83 & 0.92 \\
\hline 55 & $\begin{array}{l}\text { 12-Oxabicyclo[9.1.0]dodeca-3,7-di- } \\
\text { ene, }\end{array}$ & 26.10 & 0.60 & 0.30 & 0.38 \\
\hline 56 & $\gamma$-Cadinene & 26.99 & 0.22 & 0.08 & 0.15 \\
\hline 57 & $\alpha$-Bisabolol & 28.20 & 0.13 & 0.10 & 0.12 \\
\hline 58 & $\begin{array}{l}\text { 4,6-bis(4-methylpent-3-en-1-yl)- } \\
\text { 6-methylcyclohexa-1,3-diene-carbal- } \\
\text { dehyde }\end{array}$ & 38.64 & 0.46 & 0.26 & 0.24 \\
\hline \multirow[t]{2}{*}{59} & 1,10-Phenanthroline & 55.99 & 3.03 & - & - \\
\hline & Total & & 98.49 & 99.84 & 98.28 \\
\hline
\end{tabular}

Rt: Retention.

\section{DISCUSSION}

Similar to previous studies published by other researchers, our investigation show that plants treated with $P$. indica were superior in development to control plants. Colonization of roots by fungi has various positive effects on host performance through higher chlorophyll content [30], higher relative water content (RWC) along with greater absorption of water and mineral nutrients [10], moreover increasing the production of growth-promoting substances [4, 10], like synthesis of phytohormones [22].

Our results show that endophytic fungi helped basil to ameliorate the negative effects of salt stress, which was more obvious at higher levels of salinity. This could indicate that $P$. indica is more efficient water higher salinity and intensive salt stress. $P$. indica probably causes accumulation of sodium ions in roots and inhibits their entrance to aerial parts of plants through activation of unknown physiologic or molecular mechanisms, leading to alleviation of negative effects of salt stress [19]. 
Paclobutrazol decreases cell division in meristematic plates by lower GA levels, followed by the reduction in leaf area [28]. In our experiments, high percentage of essential oil content under PBZ treatments can be explained by the reduced leaf area leading to the increase of oil gland density. On the other hand, an increase in oil content in some of the salt-stressed plants might be attributed to the decline in the primary metabolites due to the effects of salinity, causing intermediary products to become available for secondary metabolites synthesis [17]. However, under higher salinity levels, only a few numbers of plants reached to the flowering stage. Given that the highest amount of basil essential oil is achieved in the full bloom stage [8], so not reaching to flowering stage together with few number of full bloom plants could be the cause of low essential oil content in basil plants of 6 and $9\left(\mathrm{ds} \mathrm{m}^{-1}\right)$ salinity level treatments.

It should be noted that despite the fact that application of PBZ decreased growth parameters of basil, it was effective in ameliorating the negative effects of salinity on essential oil yield. It could be argued that PBZ-treated plants had an improved quality of growth, with less foliar necrosis, milder symptom expression, less defoliation [6] and ameliorated dehydration through osmotic balance [12].

In our study, essential oil content and following that, essential oil yield was significantly increased in basil plants inoculated with $P$. indica compared to control plants. The observed modification in the synthesis of essential oils can be considered as a defense response to fungal colonization. Considering the fungicide properties of several essential oils [25] it may be that such a relation exists in the case of the fungal symbiosis. The increased in essential oils in fungi treated $O$. basilicum plants could also be related to the increased number of peltate glands, the structures responsible for oil production [9]. The higher number of glands can be related to alterations in the hormonal profile of the plants as higher levels of auxins, cytokinins, and gibberellins were recorded in inoculated plants [2]. In addition to all mentioned above, significant increase of basil dry weight and leaf area in inoculation treatments (Tables 1 and 2) can be the most effective factor of the modification of essential oil content and essential oil yield. This was more evident when these plants were under salinity stress. However, generally, oil composition differences in all treatments were not significant in our study. Moreover, the differences were not observed in important compounds such as esteragole, geranial and neral (two isomers of citral). High quantities of esteragole and citral in the oil samples make them most important in an economic point of view.

Besides the effects of salinity, endophytic fungi symbiosis and PBZ application on essential oil contents, other factors, like environmental and genetic factors and different chemocultivars, can also influence the oil composition. $P$. indica potentially represent an alternative way of promoting growth of the medicinal herb, sweet basil, especially under environmental stress conditions, as natural ways of growing such crops are currently highly sought after in the herbal industry. 


\section{REFERENCES}

1. Adams, R. P. (2007) Identification of essential oil components by gas chromatography/mass spectrometry. Allured Publ. Corp., San Diego.

2. Allen, M. F., Moore, Jr. T. S. Christensen, M. (1980) Phytohormone changes in Bouteloua gracilis infected by vesicular-arbuscular mycorrhizae: I. Cytokinin increases in the host plant. Can. J. Bot. 58 , 371-374.

3. Ansari, M. W., Trivedi, D. K., Sahoo, R. K., Gill, S. S., Tuteja, N. (2013) A critical review on fungi mediated plant responses with special emphasis to Piriformospora indica on improved production and protection of crops. Plant Physiol. Biochem. 70, 403-410.

4. Ashoori, M., Ashraf, S., Alipour, Z. T. (2015) Investigating the effect of two species of mycorrhiza fungi and salinity on growth, function and chlorophyll content on Ocimum basilicum. Intl. J. Agri. Crop Sci. 8, 503-509.

5. Baltruschat, H., Fodor, J., Harrach, B. D., Niemczyk, E., Barna, B., Gullner, G., Janeczko, A., Kogel, K. H., Schäfer, P., Schwarczinger, I., Zuccaro, A. (2008) Salt tolerance of barley induced by the root endophyte Piriformospora indica is associated with a strong increase in antioxidants. New Phytol. 180, 501-510.

6. Bañón, S., González, A., Cano, E. A., Franco, J. A., Fernández, J. A. (2002) Growth, development and colour response of potted Dianthus caryophyllus cv. Mondriaan to paclobutrazol treatment. Sci. Hortic. 94, 371-377.

7. Bauer, K., Garbe, D., Surburg, H. (2008) Common fragrance and flavor materials: preparation, properties and uses. Wiley-VCH Verlag, Weinheim, Germany.

8. Carvalho Filho, J. L., Blank, A. F., Alves, P. B., Ehlert, P. A., Melo, A. S., Cavalcanti, S. C., ArrigoniBlank, M. D., Silva-Mann, R. (2006) Influence of the harvesting time, temperature and drying period on basil (Ocimum basilicum L.) essential oil. Rev. Bras. Farmacogn. 16, 24-30.

9. Copetta, A., Lingua, G., Berta, G. (2006) Effects of three AM fungi on growth, distribution of glandular hairs, and essential oil production in Ocimum basilicum L. var. Genovese. Mycorrhiza 16 485-494.

10. Dolatabadi, H. K., Goltapeh, E. M., Moieni, A., Jaimand, K., Sardrood, B. P., Varma, A. (2011) Effect of Piriformospora indica and Sebacina vermifera on plant growth and essential oil yield in Thymus vulgaris in vitro and in vivo experiments. Symbiosis 53, 29-35.

11. Ghahfarokhi, R. M., Goltapeh, M. E. (2010) Potential of the root endophytic fungus Piriformospora indica; Sebacina vermifera and Trichoderma species in biocontrol of take-all disease of wheat Gaeumannomyces graminis var. tritici in vitro. J. Agric. Technol. 6, 11-18.

12. Hajihashemi, S., Kiarostami, K., Enteshari, S., Saboora, A. (2006) The effects of salt stress and paclobutrazol on some physiological parameters of two salt tolerant and salt sensitive cultivars of wheat. Pak. J. Biol. Sci. 9, 1370-1374.

13. Haque, M. A., Hossain, M. S., Rahman, M. Z., Rahman, M. R., Hossain, M. S., Mosihuzzaman, M., Nahar, N., Khan, S. I. (2005) Isolation of bioactive secondary metabolites from the endophytic fungus of Ocimum basilicum. J. Pharm. Sci. 4, 127-130.

14. Hussain, A. I., Anwar, F., Sherazi, S. T., Przybylski, R. (2008) Chemical composition, antioxidant and antimicrobial activities of basil (Ocimum basilicum) essential oils depends on seasonal variations. Food. Chem. 108, 986-995.

15. Käfer, E. (1977) Meiotic and mitotic recombination in Aspergillus and its chromosomal aberrations. Adv. Genet. 19, 33-131.

16. Manivannan, P., Jaleel, C. A., Kishorekumar, A., Sankar, B., Somasundaram, R., Panneerselvam, R. (2008) Protection of Vigna unguiculata (L.) Walp. plants from salt stress by paclobutrazol. Colloids Surf. B Biointerfaces, 61, 315-318.

17. Morales, C., Cusido, R. M., Palazon, J., Bonfill, M. (1993) Tolerance of mint plants to soil salinity. J. Indian Soc. Soil Sci. 44, 184-186. 
18. Oelmüller, R., Sherameti, I., Tripathi, S., Varma, A. (2009) Piriformospora indica, a cultivable root endophyte with multiple biotechnological applications. Symbiosis 49, 1-7.

19. Sepahri, M., Saleh Rastin, N., Hossieni Salkedeh, G., Khayam Nekouie, M. (2009) Effect of endophytic fungus, Piriformospora indica, on growth and resistance of Hordeum vulgare L. to salinity stress. Rangeland 3, 508-518 (In Persian).

20. Sharafzadeh, S., Zare, M. (2011) Influence of growth regulators on growth and secondary metabolites of some medicinal plants from Lamiaceae family. Adv. Environ. Biol. 1, 2296-2303.

21. Sun, C., Johnson, J. M., Cai, D., Sherameti, I., Oelmüller, R., Lou, B. (2010) Piriformospora indica confers drought tolerance in Chinese cabbage leaves by stimulating antioxidant enzymes, the expression of drought-related genes and the plastid-localized CAS protein. J. Plant. Physiol. 167, 10091017.

22. Vadassery, J., Ritter, C., Venus, Y., Camehl, I., Varma, A., Shahollari, B., Novák, O., Strnad, M. Ludwig-Müller, J., Oelmüller, R. (2008) The role of auxins and cytokinins in the mutualistic interaction between Arabidopsis and Piriformospora indica. Mol. Plant-Microbe Interact. 21, 1371-1383.

23. Varma, A., Verma, S., Sahay, N., Bütehorn, B., Franken, P. (1999) Piriformospora indica, a cultivable plant-growth-promoting root endophyte. Appl. Environ. Microbiol. 65, 2741-2744.

24. Vierheilig, H., Coughlan, A. P., Wyss, U., Piché, Y. (1998) Ink and vinegar, a simple staining technique for arbuscular-mycorrhizal fungi. Appl. Environ. Microbiol. 64, 5004-5007.

25. Vos, C. M., Yang, Y., De Coninck, B., Cammue, B. P. (2014) Fungal (-like) biocontrol organisms in tomato disease control. Biol. Control, 74, 65-81.

26. Wogiatzi, E., Papachatzis, A., Kalorizou, H., Chouliara, A., Chouliaras, N. (2011) Evaluation of essential oil yield and chemical components of selected basil cultivars. Biotechnol. Equip. 25, 25252527.

27. World Health Organization. (2011) Traditional medicine fact sheet No 134. December, 2008.

28. Yeshitela, T., Robbertse, P. J., Stassen, P. J. (2004) Paclobutrazol suppressed vegetative growth and improved yield as well as fruit quality of 'Tommy Atkins' mango (Mangifera indica) in Ethiopia. N. Z. J. Crop Hortic. Sci. 32, 281-293.

29. Zhang, H. W., Song, Y. C., Tan, R. X. (2006) Biology and chemistry of endophytes. Nat. Prod. Rep. 23, 753-771.

30. Zuccarini, P., Okurowska, P. (2008) Effects of mycorrhizal colonization and fertilization on growth and photosynthesis of sweet basil under salt stress. J. Plant Nutr. 31, 497-513. 